\title{
KONTRIBUSI MATA KULIAH KEPENDIDIKAN TERHADAP KOMPETENSI MAHASISWA PPL PENDIDIKAN TEKNIK SIPIL DAN PERENCANAAN UNM
}

\author{
Silvether Tandi \\ Universitas Negeri Makassar \\ silvether@yahoo.com \\ Sunaryo Soenarto \\ Universitas Negeri Yogyakarta \\ sunaryos_ft@yahoo.com
}

\begin{abstract}
Abstrak
Penelitian ini bertujuan untuk mengetahui besarnya kontribusi: (1) Prestasi mahasiswa pada mata kuliah Rancangan Pendidikan dan pembelajaran, (2) Prestasi mahasiswa pada mata kuliah Profesi Keguruan, (3) Prestasi mahasiswa pada mata kuliah Interaksi Pembelajaran, dan (4) Prestasi mahasiswa pada mata kuliah Rancangan Pendidikan dan Pembelajaran, Profesi Keguruan, dan Interaksi Pembelajaran terhadap kompetensi mahasiswa PPL Jurusan Pendidikan Teknik Sipil dan Perencanaan, Universitas Negeri Makassar. Jenis Penelitian adalah penelitian expost facto yang menggunakan analisis kuantitatif. Penelitian ini dilaksanakan di Provinsi Sulawesi Selatan. Populasi dalam penelitian ini adalah 35 mahasiswa yang sedang melaksanakan PPL dan 32 dijadikan sampel penelitian. Pengumpulan data dilakukan dengan observasi dan dokumentasi. Analisis data menggunakan analisis regresi ganda. Variabel terikat $(Y)$ dalam penelitian ini adalah kompetensi mahasiswa PPL, sedangkan variabel bebas (X) adalah prestasi mahasiswa pada mata kuliah Rancangan Pendidikan dan pembelajaran $\left(X_{\nu}\right)$, prestasi mahasiswa pada mata kuliah Profesi Keguruan $\left(X_{2}\right)$, dan prestasi mahasiswa pada mata kuliah Interaksi Pembelajaran $\left(X_{3}\right)$. Hasil penelitian ini menunjukkan bahwa: (1) prestasi mahasiswa pada mata kuliah Rancangan Pendidikan dan pembelajaran berkontribusi positifterhadap kompetensi mahasiswa; (2) prestasi mahasiswa pada mata kuliah Profesi Keguruan berkontribusi positif terhadap kompetensi mahasiswa; (3) prestasi mahasiswa pada mata kuliah Interaksi Pembelajaran berkontribusi positif terhadap kompetensi mahasiswa. (4) prestasi mahasiswa pada mata kuliah Rancangan Pendidikan dan Pembelajaran, Profesi Keguruan, dan Interaksi Pembelajaran secara bersama-sama berkontribusi positif terhadap kompetensi mahasiswa.
\end{abstract}

Kata Kunci: kompetensi mahasiswa PPL, Rancangan Pendidikan dan pembelajaran, Profesi Keguruan, Interaksi Pembelajaran.

\section{THE CONTRIBUTION OF EDUCATIONAL SUBJECT TO THE COMPETENCY IN PPL OF THE STUDENTS OF EDUCATION DEPARTMENT OF CIVIL ENGINEERING AND PLANNING, UNM}

\begin{abstract}
This study aims to reveal the contribution of: (1) education plans and learning subject, (2) teaching profession subject, (3) teaching and interaction subject, and (4) education plans and learning subject, teaching profession and learning interaction subjects together to the competence of the field work students of the Education Department of Civil Engineering and Planning, State University of Makassar.This research is an ex post facto study using the quantitative analysis. The research was conducted in the South Sulawesi Province. The population was 35 students of who did the field work, and 32 student of them as the research sample. The date were collected through questionnaires and observation. The analysis of the data used the regression analysis. The dependent variable $(Y)$ in this study was students' competence in the field work, while the independent variable $(X)$ was their
\end{abstract}


achievement of education plans and learning subject $\left(X_{)}\right)$, their achievement of teaching profession subject $\left(X_{2}\right)$, and their achievement of the learning interaction subject $\left(X_{3}\right)$. The results of this study show that : (1) The students' achievement of the education plans and learning subject contribute positively to their competence; (2) The students' achievement of the teaching profession subject contributes positively to their competence; (3) The students' achievement of the learning interactions subject contributes positively to their competence; (4) The students' achievement of teaching and learning subject, teaching profession subject, and learning interactions subject together contribute positively to their.

Keywords: competence, field work, the teaching and learning, the teaching profession, the learning interaction.

\section{PENDAHULUAN}

Pendidikan memegang peran yang sangat penting untuk menghadapi era globalisasi secara efektif, karena melalui pendidikan inilah akan terbentuk kualitas sumber daya manusia Indonesia yang berakhlak mulia, seperti yang tertuang dalam Pasal 3 Undang-Undang No. 20 tahun 2003 tentang Sistem Pendidikan Nasional sebagai berikut:

Pendidikan nasional berfungsi mengembangkan kemampuan dan membentuk watak serta peradaban bangsa yang bermartabat dalam rangka mencerdaskan kehidupan bangsa, bertujuan untuk berkembangnya potensi peserta didik agar menjadi manusia yang beriman dan bertakwa kepada Tuhan Yang Maha Esa, beraklak mulia, sehat, berilmu, cakap, kreatif, mandiri, dan menjadi warga negara yang demokratis serta bertanggung jawab.

Mengingat pentingnya pendidikan sebagai sarana peningkatan kualitas sumber daya manusia, maka peningkatan mutu pendidikan merupakan suatu keharusan yang segera dilaksanakan. Pendidikan yang berkualitas dan merata adalah fondasi kuat untuk melahirkan bangsa yang maju dan modern yang memahami prinsip-prinsip demokrasi (Supriano, 2013, p. 44). Peningkatan mutu pendidikan ditentukan oleh kesiapan sumber daya manusia yang terlibat dalam proses pendidikan, yang salah satu komponen utamanya adalah guru. Guru memiliki peran yang sangat penting dalam mewujudkan tujuan dari pendidikan nasional karena pencapaian kompetensi siswa tersebut dipengaruhi oleh guru. Seorang guru selain bertugas memberikan pengetahuan dan keterampilan juga bertanggungjawab dalam perkembangan potensi siswa itu sendiri. Tugas dan peran seorang guru saat ini semakin berat seiring perkembangan ilmu pengetahuan dan teknologi. Sehingga diperlukan seorang guru sebagai tenaga pendidik yang profesional.

Menjadi guru yang profesional merupakan salah satu syarat mewujudkan pendidikan yang bermutu. Undang-Undang No. 14 Tahun 2005 pasal 10 tentang Guru dan Dosen menyatakan bahwa seorang guru harus memiliki empat kompetensi yang mendukung tugas mengajar. Dengan memiliki keempat kompetensi tersebut seorang guru nantinya dapat melaksanakan tugas mengajar dengan baik. Peningkatan kualitas sumber daya manusia sangat tergantung pada kualitas pelaksanaan pendidikan formal maupun pendidikan nonformal. Institusi pendidikan merupakan tempat berlangsungnya proses pendidikan formal. Lembaga Pendidikan Tenaga Kependidikan (LPTK) merupakan lembaga yang melaksanakan jenis pendidikan formal yang bertujuan untuk menyiapkan dan mengembangkan mahasiswanya menjadi calon pendidik yang profesional dibidangnya. Seiring dengan berkembangnya ilmu pengetahuan dan teknologi serta arus globalisasi, keberadaan pendidikan tinggi dipandang sebagai salah satu faktor penentu kemajuan suatu bangsa. Sebagaimana diamanahkan dalam visi Kementerian Pendidikan dan Kebudayaan, insan Indonesia yang cerdas dan kompetitif dapat diwujudkan melalui pendidikan berkualitas yang tersedia dalam setiap jenjang pendidikan, terjangkau oleh semua lapisan masyarakat, relevan terhadap pembangunan, kesetaraan serta kepastian dalam memperoleh pendidikan.(http://www.dikti.go.id/id/profildikti/kata-sambutan-dirjen/?lang=id). 
Keberhasilan lembaga pendidikan ditentukan oleh seluruh sumber daya yang berperan dalam penyelenggaraannya. Hai ini sejalan dengan pendapat Yohanes Surya yang mengatakan bahwa, jika Indonesia ingin menjadi negara yang hebat maka stakeholder pendidikan pun juga harus hebat (http://kampus. okezone. com/read/2013/06/12/560/820856/ anak-indonesia-bisa-hebat-jika-gurunyahebat). Oleh karena itu, lembaga penyelenggara pendidkan tenaga keguruan harus memikirkan strategi yang sesuai dalam menyajikan bahan ajar dengan urutan dan konsep yang tepat untuk mendapatkan dan menghasilkan calon pendidik yang berkualitas sehingga mempunyai kompetensi, keberanian dan kepercayaan diri untuk menjalankan profesinya sebagai calon pendidik. Hal ini sejalan dengan pendapat M.Nuh (Suprianto, 2013, p. 44) mengatakan bahwa untuk mencapai pendidikan yang berkualitas dan berkeadilan menuju Indonesia yang demokratis maju dan modern, setidaknya ada 4 hal penting dan mendesak yang harus segera diperbaiki, salah satunya adalah peningkatan kualitas guru.

Untuk mendapatkan calon pendidik (Guru) yang mempunyai kualitas yang baik, keberanian dan kepercayaan diri yang tinggi dalam menjalankan tugasnya dibutuhkan metode dan latihan khusus di lembaga atau kampus dimana mereka belajar sebelum terjun ke lapangan dalam hal ini sekolah-sekolah yang telah menjadi mitra dari Universitas, persiapan dan pembekalan kepada mahasiswa mengenai segala sesuatu yang akan menjadi tugas seorang pendidik harus diberikan kepada setiap calon pendidik yang akan melakukan praktik, sehingga mahasiswa menjadi siap saat diperadabkan pada situasi nyata di lapangan.

Praktik pengalaman lapangan (PPL) di Universitas Negeri Makassar adalah salah satu program yang ditujukan kepada setiap mahasiswa calon tenaga pendidik untuk turun langsung di lapangan melihat, mempelajari dan mengimplementasikan ilmu atau teoriteori yang telah didapat pada saat kuliah di kampus untuk mendapatkan kompetensi yang profesional. PPL merupakan salah satu program pengembangan kemampuan praktik kependidikan. Dengan kompetensi tersebut diharapkan para lulusan siap untuk dapat bekerja sesuai dengan situasi dan kebutuhan lapangan khususnya tenaga kependidikan atau Guru.

Mahasiswa akan melaksanakan PPL selama satu semester penuh (6 bulan) di sekolah-sekolah setelah mengikuti semua mata kuliah kependidikan yang ada di jurusan Pendidikan Teknik Sipil dan Perencanaan UNM dengan predikat lulus. Program PPL diprogramkan pada semester 6 (Enam) sebagai mata kuliah tunggal dan tidak digabungkan dengan mata kuliah lainnya dengan tujuan memberikan waktu yang cukup kepada mahasiswa sebagai calon guru untuk berlatih meningkatkan kompetensinya dengan diperadapkan pada situasi nyata di lapangan bukan lagi di bangku kuliah. Untuk terlaksananya PPL dengan maksimal, sebelum melaksanakan PPL di sekolah-sekolah mitra, mahasiswa dibekali dan dipersiapkan secara matang mengenai materi yang berhubungan dengan profesi tenaga pendidik dan apa saja yang akan menjadi tugas yang dikerjakan pada saat berada di lokasi PPL.

Pembekalan kepada mahasiswa di kampus secara teoritik sangat dibutuhkan untuk pengembangan kompetensi pada saat melaksanakan PPL, karena mahasiswa tinggal mengaplikasikan apa yang telah didapatkan di bangku kuliah bukan lagi mencari. LPTK dalam hal ini sebagai lembaga Pembina calon pendidik memberikan bekal teotitis dalam bentuk pembelajaran maupun praktik pada mata kuliah kependidikan, seperti mata kuliah Rancanagn Pendidikan dan Pembelajaran, Profesi Keguruan, Interaksi Pembelajaran (Micro teaching), Media Pembelajaran, Perkembangan Peserta Didik, Psikologi Pendidikan dsb.

Rancangan Pendidikan dan Pembelajaran merupakan salah satu mata kuliah kependidikan yang wajib ditempuh mahasiswa dengan predikat lulus sebelum melaksanakan PPL. Rancangan Pendidikan dan Pembelajaran ini merupakan salah satu mata kuliah dimana mahasiswa dapat belajar bagaimana merancang pembelajaran yang baik. Pembelajaran difokuskan pada perencanaan perangkat pembelajaran di 
dalamnya mencakup bagaimana merancang bahan ajar, bagaimana merancang silabus mata pelajaran, dan bagaimana merancang rencana pelaksanaan pembelajaran (RPP). Dengan bekal pada mata pelajaran ini mahasiswa diharapkan mempunyai kompetensi dalam hal perancangan perangkat pembelajaran sehingga mampu memperlihatkan kinerja yang baik pada saat melaksanakan praktik pengalaman lapangan.

Kompetensi yang baik perlu didukung oleh sikap (attitude) yang baik. Untuk mendukung terciptanya sikap yang baik pada saat melaksanakan PPL dan juga diharapkan menjadi bekal pada saat menjadi guru profesional, mahasiswa perlu tahu apa yang menjadi tugas guru, baik di lingkungan sekolah maupun masyarakat. Mata kuliah profesi keguruan merupakan salah satu mata kuliah kependidikan dimana mahasiswa dalam pembelajaran mendapatkan materi mengenai tugas dan tanggung jawab seorang guru, bagaimana berbusana yang baik, bagaimana bersikap maupun bertindak yang baik. Hal ini sejalan dengan pendapat Sanjaya (2011, p. 133) yang menyatakan bahwa terdapat beberapa aspek dalam setiap kompetensi guru, antara lain di dalamnya ada: (1) Nilai (Value) merupakan norma-norma yang dianggap baik oleh setiap individu, (2) sikap (attitude) pandangan seseorang terhadap sesuatu. Sehingga diharapkan mahasiswa mempunyai sikap yang baik karna akan menjadi contoh atau panutan bagi siswanya.

Kemampuan mahasiswa dalam memberikan contoh yang baik kepada siswanya biasa dilakukan dengan berbagai cara, dengan berpakaian yang sopan, bertindak sesuai dengan norma dan yang lebih penting adalah kemampuan mahasiswa dalam berkomunikasi di depan kelas. Kemampuan berdiri dan berkomunikasi di depan kelas sangat dibutuhkan bagi seorang guru untuk menunjang terlaksananya pembelajaran dengan baik. Dalam hal ini mahasiswa telah dilatih di kampus pada pembelajaran interaksi pembelajaran (micro teaching) dimana mahasiswa berlatih bagaimana cara mengajar yang baik dan dilakukan di depan teman-teman sendiri. Hal ini dimaksudkan agar nantinya mahasiswa pada saat melaksanakan PPL mempunyai kepercayaan diri yang baik untuk berbicara dan berdiri di depan kelas. Pada mata kuliah interaksi pembelajaran ini juga dilatih kompetensi dasar mengajar bagi seorang guru, mulai dari teknik membuka dan menutup pelajaran, keterampilan bertanya, keterampilan memberi penguatan, keterampilan mengadakan variasi, keterampilan menjelaskan, keterampilan membimbing diskusi kecil, keterampilan mengelola kelas, dan keterampilan mengajar perorangan dan kelompok kecil.

Pemberian bekal di kampus merupakan salah satu cara mempersiapkan mahasiswa dalam melaksanakan praktik pengalaman lapangan (PPL) di sekolah yang diharapkan mampu membawa perubahan yang baru dalam hal penggunaan teknologi, metode pembelajaran yang kreatif, kemahiran dalam pembuatan perangkat pembelajaran yang sebelumnya telah dipraktikkan di kampus sebelum turun ke lapangan tidak sesuai dengan apa yang diharapkan.

Sesuai dengan hasil prasurvei yang telah dilaksanakan pada bulan Agustus 2013 di sekolah-sekolah mitra dari Universitas Negeri Makassar, dimana selama ini menjadi tempat pelaksanaan kegiatan Praktik Pengalaman Lapangan (PPL) mendapatkan data bahwa kompetensi mahasiswa menurun dalam beberapa tahun terakhir dilihat dari segi kedisiplinan mahasiswa datang di sekolah, etika penampilan maupun sikap di lingkungan sekolah, banyaknya mahasiswa yang gagap dan merasa asing ketika diberikan tugas untuk membuat perangkat pembelajaran dalam hal ini RPP dan silabus, mahasiswa merasa tidak percaya diri saat harus berdiri di depan siswa yang akan diajarnya dan merasa kebingungan tentang apa yang akan dilakukan. Pada dasarnya secara teoritis semuanya telah didapatkan di bangku kuliah, khususnya dalam pembelajaran mata kuliah kependidikan. Hal ini diperkuat dengan pendapat Wasilatul (2013, p. 907) menyatakan bahwa fakta di lapangan menunjukkan bahwa beberapa mahasiswa calon guru ketika terjun ke lapangan (PPL) masih banyak yang sering melihat buku ketika menerangkan pelajaran kepada siswa, 
Tabel 1. Daftar Sekolah tempat pelaksanaan penelitian

\begin{tabular}{ll}
\hline Nama Sekolah & Kabupaten Kota \\
\hline SMK Negeri 3 Makassar. & Kota Makassar \\
SMK Negeri 2 Somba Opu Sungguminasa & Kabupaten Gowa \\
SMK Negeri 2 Pare-Pare. & Kota Pare-pare \\
SMK Negeri 2 Sidenreng & Kabupaten Sidrap \\
SMK Negeri 1 Watampone & Kabupaten Bone \\
\hline
\end{tabular}

Tabel 2. Jumlah Populasi dan sampel Penelitian.

\begin{tabular}{lcc}
\hline Tempat & Populasi & Sampel \\
\hline SMK Negeri 3 Makassar. & 3 & 3 \\
SMK Negeri 2 Somba Opu Sungguminasa. & 4 & 4 \\
SMK Negeri 2 Pare-Pare. & 8 & 7 \\
SMK Negeri 2 Sidenreng. & 9 & 8 \\
SMK Negeri 1 Watampone. & 11 & 10 \\
\hline Jumlah & $\mathbf{3 5}$ & $\mathbf{3 2}$ \\
\hline
\end{tabular}

salah konsep dalam menerangkan dan salah menjawab pertanyaan dari siswa. Hal ini menunjukkan bahwa kompetensi professional mahasiswa sebagai calon guru masih kurang.

Calon pendidik yang seharusnya diharapkan mampu berkontribusi terhadap kemajuandunia pendidikan dengan peningkatan kualitas sumber daya yang dimilikinya harus terus dikembangkan agar tercipta pendidik yang benar-benar bisa diandalkan. Bertolak dari latar belakang dan masalah yang ada, maka dilakukanlah peneltian dengan judul "Kontribusi Mata Kuliah Kependidikan Terhadap Kompetensi Mahasiswa Praktik Pengalaman Lapangan (PPL) pada Jurusan Pendidikan Teknik Sipil dan Perencanaan Universitas Negeri Makassar".

\section{METODE PENELITIAN}

Penelitian ini mengkaji Kontribusi mata kuliah Kependidikan terhadap Kompetensi Mahasiswa Praktik Pengalaman Lapangan (PPL) Jurusan Pendidikan Teknik Sipil dan Perencanaan Universitas Negeri Makassar. Penelitian ini termasuk penelitian ex-post facto. Penelitian ini dilaksanakan pada lima
SMK di Provinsi Sulawesi Selatan dimana SMK tersebut digunakan sebagai tempat PPL oleh mahasiswa. Populasi dalam penelitian ini adalah mahasiswa Jurusan Pendidikan Teknik Sipil dan Perencanaan Universitas Negeri Makassar yang sedang melaksanakan PPL di SMK. Jumlah mahasiswa yang sedang melaksanakan PPL sebanyak 35 orang yang tersebar di kelima SMK dan digunakan sebagai populasi. Sukardi (2003, p. 53) menyatakan bahwa populasi pada prinsipnya adalah semua anggota kelompok manusia, binatang, peristiwa atau benda yang tinggal bersama dalam suatu tempat dan secara terencana menjadi target kesimpulan dari hasil akhir suatu penelitian. Secara lengkap populasi penelitian ini ditunjukkan pada Tabel 1 .

Sugiyono (2012, p. 118) sampel adalah bagian dari jumlah dan karakteristik yang dimiliki oleh populasi tersebut. Jumlah populasi dalam penelitian ini adalah 35 mahasiswa yang sedang melaksanakan PPL. Sampel dari penelitian ini adalah 32 orang sesuai tabel Isaac (1983, p. 251).

Teknik pengambilan sampel yang digunakan pada penelitian ini adalah teknik 
probability random sampling. Dengan sampling acak maka semua populasi penelitian ini secara bersama-sama mempunyai peluang yang sama untuk dijadikan sebagai sampel penelitian. Variabel bebas dalam penelitian ini terdiri dari Prestasi mahasiswa pada mata kuliah Rancangan Pendidikan dan Pembelajaran, Prestasi mahasiswa pada mata kuliah Profesi Keguruan, dan Prestasi mahasiswa pada mata kuliah Interaksi Pembelajaran, sedangkan variabel terikatnya adalah Kompetensi mahasiswa PPL di SMK. Untuk mendapatkan data tentang variabel yang diselidiki dalam penelitian ini, digunakan seperangkat instrumen yang berbentuk lembar observasi. Penelitian ini menggunakan model observasi model ceklis dengan pernyataan tertutup model Likert.

\section{HASIL PENELITIAN DAN PEMBAHASAN}

\section{Deskripsi Variabel Penelitian}

\section{Prestasi Mahasiswa Pada Mata Kuliah Rancangan Pendidikan dan Pembelajaran.}

Tabel 3. Distribusi frekuensi prestasi mahasiswa pada mata kuliah rancangan pendidikan dan pembelajaran

\begin{tabular}{lccc}
\hline No & $\begin{array}{c}\text { Kelas } \\
\text { Interval } \\
\text { Aktual }\end{array}$ & $\begin{array}{c}\text { Total } \\
\text { Frekuensi } \\
(\mathbf{\%})\end{array}$ & $\begin{array}{c}\text { Relatif } \\
\text { Aktual }\end{array}$ \\
\hline 1 & 4 & 9 & 28,125 \\
2 & 3 & 20 & 62,5 \\
3 & 2 & 3 & 9,375 \\
Jumlah & & $\mathbf{3 2}$ & $\mathbf{1 0 0}$ \\
\hline
\end{tabular}

Analisis deskriptif variabel Prestasi Mahasiswa Pada Mata Kuliah Rancangan Pendidikan dan Pembelajaran menggunakan persen (percentages correction), distribusi frekuensi, skor maksimum, skor minimum, jumlah total nilai variabel (sum) dan interpretasi deskriptif dari setiap variabel. Data prestasi mahasiswa pada mata kuliah rancangan pendidikan dan pembelajaran diperoleh dari hasil nilai ujian akhir semester yang telah ada. Nilai minimal mahasiswa sesuai dengan daftar penetapan nilai akhir (DPNA) yang di dapat dari jurusan Pendidikan Teknik Sipil dan Perencanaan Universitas Negeri Makassar adalah C (2) dan nilai maksimal adalah A (4). Rentang skor penilaian adalah $0,1,2,3$, dan 4. Distribusi frekuensi skor variabel prestasi mahasiswa pada mata kuliah rancangan pendidikann dan pembelajaran dapat dilihat pada tabel 3 .

Tabel 3 tersebut menunjukkan bahwa berdasarkan nilai yang diperoleh melalui DPNA dari prodi Pendidikan Teknik Sipil dan Perencanaan Universitas Negeri Makassar sebagaimana yang disajikan pada gambar 1, frekuensi prestasi mahasiswa pada mata kuliah Rancangan Pendidikan dan Pembelajaran pada nilai 4 sebanyak $9(28,125 \%)$ responden, nilai 3 sebanyak $20(62,5 \%)$ responden, dan nilai 2 sebanyak $3(9,375 \%)$ responden.

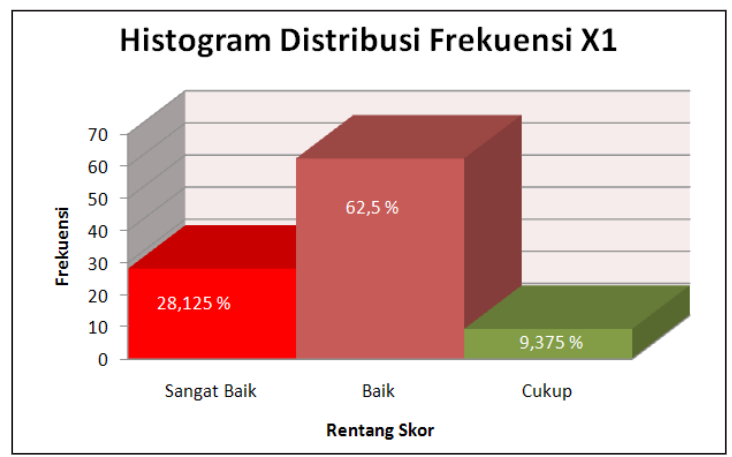

Gambar 1. Histogram skor prestasi mahasiswa pada mata kuliah rancangan pendidikan dan pembelajaran.

Skor ideal prestasi mahasiswa pada mata kuliah rancangan pendidikan dan pembelajaran adalah $4 \times 32=128$. Nilai yang didapat dengan menggunakan DPNA oleh mahasiswa menunjukkan Nilai total variabel prestasi mahasiswa pada mata kuliah rancangan pendidikan dan pembelajaran sebesar 102. Prestasi mahasiswa pada mata kuliah rancangan pendidikan dan pembelajaran jurusan Pendidikan Teknik Sipil dan Perencanaan Universitas Negeri Makassar dapat dihitung dengan cara $102: 128=0,796$. Sehingga prestasi mahasiswa sebesar 79,60 $\%$ dari hasil $100 \%$ yang diharapkan. Prestasi mahasiswa tersebut masuk dalam kategori baik. Dari uraian di atas untuk lebih jelasnya dapat dilihat pada tabel 4. 
Tabel 4. Skor total pencapaian prestasi Mahasiswa dari skor maksimal mata kuliah Rancangan Pendidikan dan Pembelajaran.

\begin{tabular}{cccc}
\hline Data Kuantitatif & Rentang & Skor Prestasi Mahasiswa & Data Kualitatif \\
\hline 4 & $86-100 \%$ & & Sangat baik \\
3 & $76-85 \%$ & $79,60 \%$ & Baik \\
2 & $56-75 \%$ & & Cukup baik \\
1 & $10-55 \%$ & & Kurang baik \\
\hline
\end{tabular}

\section{Prestasi Mahasiswa Pada Mata Kuliah Profesi Keguruan.}

Analisis deskriptif variabel Prestasi Mahasiswa Pada Mata Kuliah Profesi Keguruan Data prestasi mahasiswa pada mata kuliah Profesi Keguruan diperoleh dari hasil nilai ujian akhir semester yang telah ada. Nilai minimal mahasiswa sesuai dengan daftar penetapan nilai akhir (DPNA) yang di dapat dari jurusan Pendidikan Teknik Sipil dan Perencanaan Universitas Negeri Makassar adalah C (2) dan nilai maksimal adalah A (4). Rentang skor penilaian adalah $0,1,2,3$, dan 4. Distribusi frekuensi skor variabel prestasi mahasiswa pada mata kuliah Profesi Keguruan dapat dilihat pada tabel berikut:

Tabel 5. Distribusi Frekuensi Variabel Prestasi mahasiswa pada mata kuliah Profesi Keguruan

\begin{tabular}{lccc}
\hline No & $\begin{array}{c}\text { Kelas } \\
\text { Interval } \\
\text { Aktual }\end{array}$ & $\begin{array}{c}\text { Total } \\
\text { Frekuensi } \\
\text { (\%) }\end{array}$ & $\begin{array}{c}\text { Relatif } \\
\text { Aktual }\end{array}$ \\
\hline 1 & 4 & 6 & 18,75 \\
2 & 3 & 22 & 68,75 \\
3 & 2 & 4 & 12,5 \\
Jumlah & & $\mathbf{3 2}$ & $\mathbf{1 0 0}$ \\
\hline
\end{tabular}

Tabel 5 tersebut menunjukkan berdasarkan nilai yang diperoleh melalui DPNA dari prodi Pendidikan Teknik Sipil dan Perencanaan Universitas Negeri Makassar frekuensi prestasi mahasiswa pada mata kuliah profesi keguruan pada nilai 4 sebanyak $6(18,75 \%)$ responden, nilai 3 sebanyak $22(68,75 \%)$ responden, dan nilai 2 sebanyak 4 (12,5\%) responden. Histogram mengenai distribusi frekuensi prestasi mahasiswa pada mata kuliah Profesi Keguruan dapat dilihat pada Gambar 2.

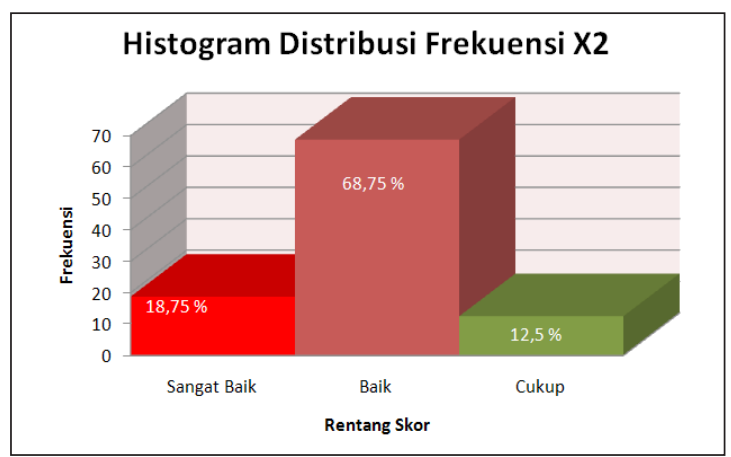

Gambar 2. Histogram Skor prestasi mahasiswa pada MK.Profesi Keguruan

Skor ideal prestasi mahasiswa pada mata kuliah profesi keguruan adalah 4 x $32=128$. Nilai yang didapat dengan menggunakan DPNA oleh mahasiswa menunjukkan Nilai total variabel prestasi mahasiswa pada mata kuliah profesi keguruan sebesar 99. Prestasi mahasiswa pada mata kuliah profesi keguruan jurusan Pendidikan Teknik Sipil dan Perencanaan Universitas Negeri Makassar dapat dihitung dengan cara $99: 128=0,773$. Sehingga prestasi mahasiswa sebesar 77,30 $\%$ dari hasil $100 \%$ yang diharapkan. Prestasi mahasiswa tersebut masuk dalam kategori baik. Dari uraian di atas untuk lebih jelasnya dapat dilihat pada tabel 6 .

\section{Prestasi mahasiswa pada mata kuliah Interaksi Pembelajaran.}

Analisis deskriptif variabel Prestasi Mahasiswa Pada Mata Kuliah Interaksi Pembelajaran. Data prestasi mahasiswa pada mata kuliah Interaksi Pembelajaran diperoleh dari hasil nilai ujian akhir semester yang telah ada. Nilai minimal mahasiswa sesuai dengan daftar penetapan nilai akhir (DPNA) yang di dapat dari jurusan Pendidikan Teknik Sipil dan Perencanaan Universitas Negeri Makassar adalah C (2) dan nilai maksimal adalah A 
Tabel 6. Skor total pencapaian prestasi Mahasiswa dari skor maksimal pada mata kuliah Profesi Keguruan

\begin{tabular}{cccc}
\hline Data Kuantitatif & Rentang & Skor Prestasi Mahasiswa & Data Kualitatif \\
\hline 4 & $86-100 \%$ & & Sangat baik \\
3 & $76-85 \%$ & $77,30 \%$ & Baik \\
2 & $56-75 \%$ & & Cukup baik \\
1 & $10-55 \%$ & & Kurang baik \\
\hline
\end{tabular}

Tabel 8. Skor total pencapaian prestasi Mahasiswa dari skor maksimal pada mata kuliah Interaksi Pembelajaran.

\begin{tabular}{cccc}
\hline Data Kuantitatif & Rentang & Skor Prestasi Mahasiswa & Data Kualitatif \\
\hline 4 & $86-100 \%$ & & Sangat baik \\
3 & $76-85 \%$ & $78,90 \%$ & Baik \\
2 & $56-75 \%$ & & Cukup baik \\
1 & $10-55 \%$ & & Kurang baik \\
\hline
\end{tabular}

(4). Rentang skor penilaian adalah $0,1,2$, 3, dan 4. Distribusi frekuensi skor variabel prestasi mahasiswa pada mata kuliah Interaksi Pembelajaran dapat dilihat pada tabel berikut:

Tabel 7. Distribusi Frekuensi Variabel Prestasi mahasiswa mata kuliah Interaksi Pembelajaran

\begin{tabular}{lccc}
\hline No & $\begin{array}{c}\text { Kelas } \\
\text { Interval } \\
\text { Aktual }\end{array}$ & $\begin{array}{c}\text { Total } \\
\text { Frekuensi } \\
\text { (\%) }\end{array}$ & $\begin{array}{c}\text { Relatif } \\
\text { Aktual }\end{array}$ \\
\hline 1 & 4 & 8 & 25 \\
2 & 3 & 21 & 65,625 \\
3 & 2 & 3 & 9,375 \\
Jumlah & & $\mathbf{3 2}$ & $\mathbf{1 0 0}$ \\
\hline
\end{tabular}

Tabel 7 tersebut menunjukkan bahwa berdasarkan nilai yang diperoleh melalui DPNA dari prodi Pendidikan Teknik Sipil dan Perencanaan Universitas Negeri Makassar frekuensi prestasi mahasiswa pada mata kuliah Interaksi Pembelajaran pada nilai 4 sebanyak 8 $(25 \%)$ responden, nilai 3 sebanyak $21(65,625$ $\%)$ responden, dan nilai 2 sebanyak $3(9,375$ $\%$ ) responden. Histogram mengenai distribusi frekuensi prestasi mahasiswa pada mata kuliah Interaksi Pembelajaran dapat dilihat pada Gambar 3 berikut.

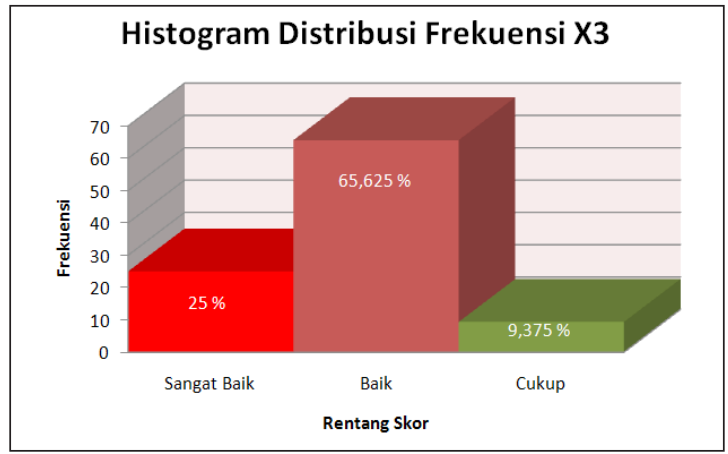

Gambar 3. Histogram skor prestasi mahasiswa pada mata kuliah Interaksi Pembelajaran.

Skor ideal prestasi mahasiswa pada mata kuliah interaksi pembelajaran adalah $4 \times 32=$ 128. Nilai yang didapat dengan menggunakan DPNA oleh mahasiswa menunjukkan Nilai total variabel prestasi mahasiswa pada mata kuliah interaksi pembelajaran sebesar 101. Prestasi mahasiswa pada mata kuliah interaksi pembelajaran jurusan Pendidikan Teknik Sipil dan Perencanaan Universitas Negeri Makassar dapat dihitung dengan cara $101: 128=0,789$. Sehingga prestasi mahasiswa sebesar 78,90 $\%$ dari hasil $100 \%$ yang diharapkan. Prestasi mahasiswa tersebut masuk dalam kategori baik. Dari uraian di atas untuk lebih jelasnya dapat dilihat pada 8 . 
Tabel 10. Skor Variabel Kompetensi Mahasiswa PPL

\begin{tabular}{cccc}
\hline Data Kuantitatif & Rentang & Skor Prestasi Mahasiswa & Data Kualitatif \\
\hline 4 & $86-100 \%$ & & Sangat baik \\
3 & $76-85 \%$ & $74,59 \%$ & Baik \\
2 & $56-75 \%$ & & Cukup baik \\
1 & $10-55 \%$ & & Kurang baik \\
\hline
\end{tabular}

Tabel 11. Hasil Pengujian Normalitas Variabel

\begin{tabular}{lcccc}
\hline No & Variabel & Skewness & Kurtosis & Kesimpulan \\
\hline 1. & $\mathrm{X}_{1}$ & $-0,054$ & $-0,160$ & Normal \\
2. & $\mathrm{X}_{2}$ & 0,007 & 0,108 & Normal \\
3. & $\mathrm{X}_{3}$ & 0,016 & 0,084 & Normal \\
4. & $\mathrm{Y}$ & $-0,153$ & $-0,145$ & Normal \\
\hline
\end{tabular}

\section{Kompetensi mahasiswa PPL.}

Data kompetensi mahasiswa diperoleh dengan menggunakan angket dengan jumlah item pertanyaan sebesar 57 dengan jumlah responden 32 orang. Skor minimal butir pertanyaan kompetensi mahasiswa PPL adalah 1 dan skor maksimal perbutirnya adalah 4 (empat alternative jawaban). Distribusi frekuensi skor variabel kompetensi mahasiswa PPL dapat dilihat pada tabel 9.

Tabel 9. Distribusi Frekuensi Variabel Kompetensi mahasiswa PLL

\begin{tabular}{lccc}
\hline No & $\begin{array}{c}\text { Kelas } \\
\text { Interval }\end{array}$ & $\begin{array}{c}\text { Total } \\
\text { Frekuensi } \\
\text { Aktual }\end{array}$ & $\begin{array}{c}\text { Relatif } \\
\text { Aktual } \\
(\mathbf{\%})\end{array}$ \\
\hline 1 & $127-147$ & 1 & 25 \\
2 & $148-158$ & 5 & 65,625 \\
3 & $159-169$ & 8 & 9,375 \\
4 & $170-180$ & 9 & 128,125 \\
5 & $181-191$ & 8 & 25 \\
6 & $192-202$ & 1 & 3,125 \\
Jumlah & $\mathbf{3 2}$ & $\mathbf{1 0 0}$ \\
\hline
\end{tabular}

Berdasarkan data yang diperoleh melalui angket sebagaimana yang telah disajikan pada tabel 9, frekuensi kompetensi mahasiswa PPL pada interval skor 137 - 147 sebanyak 1 $(3,125 \%)$ responden, interval skor $148-158$ sebanyak $5(15,625 \%)$ responden, interval 159 - 169 sebanyak 8 (25\%) responden, interval 170 - 180 sebanyak $9(28,125 \%)$ responden, interval 181 - 191 sebanyak 8 (25 \%) responden, interval $192-202$ sebanyak $1(3,125 \%)$ responden. Histogram mengenai distribusi frekuensi kompetensi mahasiswa PPL dapat dilihat pada Gambar 4 berikut.

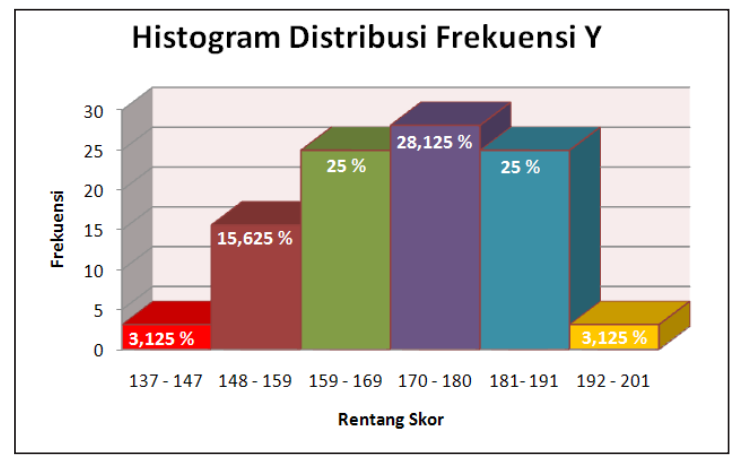

Gambar 4. Histogram Skor kompetensi mahasiswa PPL.

Skor ideal variabel terikat (Y) adalah $4 \mathrm{x}$ 57 x $32=7296$. Data lapangan yang didapat dengan menggunakan angket oleh mahasiswa menunjukkan skor total variabel kompetensi mahasiswa PPL sebesar 5508. Kompetensi mahasiswa PPL jurusan Pendidikan Teknik Sipil dan Perencanaan Universitas Negeri Makassar dapat dihitung dengan cara 5508: $7296=0,7459$. Sehingga kompetensi mahasiswa PPL sebesar 74,59\% dari hasil 100 $\%$ yang diharapkan. Kompetensi mahasiswa tersebut masuk dalam kategori cukup baik. Dari uraian di atas untuk lebih jelasnya dapat dilihat pada tabel 10 . 
Tabel 12. Hasil Pengujian Linearitas Variabel

\begin{tabular}{lcccc}
\hline No & Variabel & $\begin{array}{c}\text { F Deviation } \\
\text { From Linearity }\end{array}$ & P $>\mathbf{0 , 0 5}$ & Kesimpulan \\
\hline 1. & $\mathrm{X}_{1}-\mathrm{Y}$ & 0,401 & 0,532 & linear \\
2. & $\mathrm{X}_{2}-\mathrm{Y}$ & 0,109 & 0,744 & linear \\
3. & $\mathrm{X}_{3}-\mathrm{Y}$ & 0,501 & 0,485 & linear \\
\hline
\end{tabular}

Tabel 13. Hasil Uji Multikolinearitas Coefficients $^{\text {a }}$

\begin{tabular}{llccccc}
\hline & & \multicolumn{2}{c}{$\begin{array}{c}\text { Unstandardized } \\
\text { Coefficients }\end{array}$} & $\begin{array}{c}\text { Standardized } \\
\text { Coefficients }\end{array}$ & \multicolumn{2}{c}{$\begin{array}{c}\text { Collinearity } \\
\text { Statistics }\end{array}$} \\
\cline { 3 - 7 } Model & \multicolumn{2}{c}{ B } & Std. Error & Beta & Tolerance & VIF \\
\hline 1 & (Constant) & 169.815 & 24.680 & & & \\
& X1 & .822 & .317 & .314 & .997 & 1.003 \\
& X2 & 1.163 & .353 & .250 & .995 & 1.005 \\
& X3 & 1.547 & .452 & .265 & .998 & 1.002 \\
\hline
\end{tabular}

a. Dependent Variable: $Y$

\section{Uji Persyaratan Analisis}

Agar data yang diperoleh memenuhi persyaratan analisis regresi ganda, maka data harus memenuhi syarat normalitas, linearitas, dan multikolinearitas. Hasil uji persyaratan analisis diuraikan sebagai berikut:

\section{Uji Normalitas}

Hasil pengujian normalitas variabel dapat dilihat pada tabel 11 .

\section{Uji Linearitas}

Hasil pengujian Linearitas Variabel dapat dilihat pada tabel 12 .

\section{Uji Multikolinearitas}

Hasil uji multikolinearitas dapat dilihat pada tabel 13 .

\section{Analisis Data Penelitian}

Analisis data yang digunakan dalam penelitian ini adalah regresi ganda. Regresi ganda digunakan untuk mengetahui Pengaruh Prestasi mahasiswa pada mata kuliah Rancangan Pendidikan dan Pembelajaran, Prestasi mahasiswa pada mata kuliah Profesi Keguruan, dan Prestasi mahasiswa pada mata kuliah Interaksi Pembelajaran baik sendiri-sendiri maupun secara bersama-sama terhadap Kompetensi mahasiswa PPL jurusan pendidikan Teknik Sipil dan Perencanaan Universitas Negeri Makassar.

Kontribusi prestasi mahasiswa pada mata kuliah Rancangan Pendidikan dan Pembelajaran terhadap Kompetensi mahasiswa PPL jurusan pendidikan Teknik Sipil dan Perencanaan Universitas Negeri Makassar.

Dari hasil analisis data dengan menggunakan program SPSS, Sumbangan efektif variabel prestasi mahasiswa pada mata kuliah rancangan pendidikan dan pembelajaran $\left(\mathrm{X}_{1}\right)$ terhadap kompetensi mahasiswa PPL (Y) sebesar 9,950 \%. Artinya 90,05 \% kompetensi mahasiswa yang melaksanakan PPL dipengaruhi oleh faktor lain diluar faktor varaibel pertama tersebut. Persamaan regresinya sbb:

$$
\mathrm{Y}=169,815+0,822 \mathrm{X}_{1}
$$

Dalam persamaan tersebut $\mathrm{Y}$ adalah KompetensimahasiswaPPLjurusan pendidikan Teknik Sipil dan Perencanaan Universitas Negeri Makassar. $X_{1}$ adalah Prestasi mahasiswa pada mata kuliah Rancangan Pendidikan dan Pembelajaran. Angka 169,815 adalah intersep atau titik potong garis regresi pada sumbu $\mathrm{Y}$ ketika $\mathrm{X}_{1}=0$; sedangkan angka 0,822 adalah koefisien regresi dari $\mathrm{X}_{1}$. 
Kontribusi Prestasi mahasiswa pada mata Kuliah Profesi Keguruan terhadap Kompetensi mahasiswa PPL jurusan pendidikan Teknik Sipil dan Perencanaan Universitas Negeri Makassar.

Dari hasil analisis data dengan menggunakan program SPSS, Sumbangan efektif variabel prestasi mahasiswa pada mata kuliah profesi keguruan $\left(\mathrm{X}_{2}\right)$ terhadap kompetensi mahasiswa PPL (Y) sebesar 14,025 $\%$. Artinya 85,975 \% kompetensi mahasiswa yang melaksanakan PPL dipengaruhi oleh faktor lain diluar faktor varaibel kedua tersebut. Persamaan regresinya sbb:

$$
\mathrm{Y}=18,609+1,163 \mathrm{X}_{2}
$$

Dalam persamaan tersebut $\mathrm{Y}$ adalah Kompetensi mahasiswa PPL jurusan pendidikan Teknik Sipil dan Perencanaan Universitas Negeri Makassar. $X_{2}$ adalah Prestasi mahasiswa pada mata Kuliah Profesi Keguruan. Angka 18,609 adalah titik potong garis regresi pada sumbu $Y$ ketika $X_{2}=0$; sedangkan angka 1,163 adalah koefisien regresi dari $\mathrm{X}_{2}$.

Kontribusi Prestasi mahasiswa pada mata Kuliah Interaksi Pembelajaran terhadap Kompetensi mahasiswa PPL jurusan pendidikan Teknik Sipil dan Perencanaan Universitas Negeri Makassar.

Dari hasil analisis data dengan menggunakan program SPSS, Sumbangan efektif variabel prestasi mahasiswa pada mata kuliah interaksi pembelajaran $\left(\mathrm{X}_{3}\right)$ terhadap kompetensi mahasiswa PPL (Y) sebesar 18,725 $\%$. Artinya 81,275 \% kompetensi mahasiswa yang melaksanakan PPL dipengaruhi oleh faktor lain diluar faktor varaibel ketiga tersebut. Persamaan regresinya sbb:

$$
Y=169,815+1,547 X_{3}
$$

Dalam persamaan tersebut $\mathrm{Y}$ adalah kompetensi mahasiswa PPL jurusan pendidikan Teknik Sipil dan Perencanaan Universitas Negeri Makassar.

$\mathrm{X}_{3}$ adalah Kontribusi Prestasi mahasiswa pada mata Kuliah Interaksi Pembelajaran. Angka 169,815 adalah titik potong garis regresi pada sumbu $Y$ ketika $\mathrm{X}_{3}=0$; sedangkan angka 1,547 adalah koefisien regresi dari $\mathrm{X}_{3}$.
Kontribusi prestasi mahasiswa pada mata kuliah Rancangan Pendidikan dan Pembelajaran, Profesi Keguruan, dan Interaksi Pembelajaran secara Bersama-sama terhadap Kompetensi kompetensi mahasiswa PPL jurusan pendidikan Teknik Sipil dan Perencanaan Universitas Negeri Makassar.

Koefisien determinasi (Rsquare) antara ketiga variabel secara bersama-sama $\left(\mathrm{X}_{4}\right)$ dan kompetensi mahasiswa PPL (Y) sebesar 0,427; bahwa sumbangan efektif ketiga variabel bebas secara bersama-sama terhadap kompetensi mahasiswa PPL sebesar 42,7 \%. Artinya 57,3 $\%$ kompetensi mahasiswa yang melaksanakan PPL dipengaruhi oleh faktor lain diluar faktor ketiga varaibel bebas tersebut. Persamaan regresinya sbb:

$\mathrm{Y}=169,815+0,822 \mathrm{X}_{1}+1,163 \mathrm{X}_{2}+1,547 \mathrm{X}_{3}$.

Dalam persamaan tersebut $\mathrm{Y}$ adalah KompetensimahasiswaPPLjurusanpendidikan Teknik Sipil dan Perencanaan Universitas Negeri Makassar. $X_{1}$ adalah Prestasi mahasiswa pada mata kuliah Rancangan Pendidikan dan Pembelajaran, $X_{2}$ berarti Prestasi mahasiswa pada mata kuliah Profesi Keguruan, dan $\mathrm{X}_{3}$ adalah Prestasi mahasiswa pada mata kuliah Interaksi Pembelajaran. Angka 169,815 adalah titik potong garis regresi pada sumbu Y ketika $X_{1}, X_{2}$, dan $X_{3}=0$; sedangkan angka adalah 0,822 koefisien regresi dari $X_{1}$, angka 1,163 adalah koefisien regresi dari $\mathrm{X}_{2}$, dan angka 1,547 adalah koefisien regresi dari $\mathrm{X}_{3}$.

\section{Pembahasan}

Kontribusi prestasi mahasiswa pada mata kuliah Rancangan Pendidikan dan Pembelajaran terhadap Kompetensi mahasiswa PPL jurusan pendidikan Teknik Sipil dan Perencanaan Universitas Negeri Makassar.

Berdasarkan hasil analisis data penelitian yang telah dijelaskan di atas, terlihat bahwa skor total prestasi mahasiswa pada mata kuliah Rancangan Pendidikan dan Pembelajaran sebesar 79,60 \% dari yang diharapkan, dan berada dalam kategori baik; Selain itu, variabel Prestasi mahasiswa pada mata kuliah Rancangan Pendidikan dan Pembelajaran memberikan sumbangan efektif terhadap 
kompetensi mahasiswa PPL (Y) sebesar 9,950\%.

Kontribusi prestasi mahasiswa pada mata kuliah Profesi Keguruan terhadap Kompetensi mahasiswa PPL jurusan pendidikan Teknik Sipil dan Perencanaan Universitas Negeri Makassar.

Berdasarkan hasil analisis data penelitian yang telah dijelaskan di atas, terlihat bahwa skor total prestasi mahasiswa pada mata kuliah Profesi Keguruan sebesar 77,30 \% dari yang diharapkan, dan berada dalam kategori baik; Selain itu, variabel Prestasi mahasiswa pada mata kuliah Profesi Keguruan memberikan sumbangan efektif terhadap kompetensi mahasiswa PPL (Y) sebesar 14,025 \%.

Kontribusi prestasi mahasiswa pada mata kuliah Interaksi Pembelajaran terhadap Kompetensi mahasiswa PPL jurusan pendidikan Teknik Sipil dan Perencanaan Universitas Negeri Makassar.

Berdasarkan hasil analisis data penelitian yang telah dijelaskan di atas, terlihat bahwa skor total prestasi mahasiswa pada mata kuliah Interaksi Pembelajaran sebesar 78,90 \% dari yang diharapkan, dan berada dalam kategori baik; Selain itu, variabel Prestasi mahasiswa pada mata kuliah Interaksi Pembelajaran memberikan sumbangan efektif terhadap kompetensi mahasiswa PPL (Y) sebesar 18,725 \%.

Kontribusi prestasi mahasiswa pada mata kuliah Rancangan Pendidikan dan Pembelajaran, Profesi Keguruan, dan Interaksi Pembelajaran secara bersama-sama terhadap Kompetensi kompetensi mahasiswa PPL jurusan pendidikan Teknik Sipil dan Perencanaan Universitas Negeri Makassar.

Berdasarkan hasil analisis data penelitian yang telah dijelaskan di atas Koefisien determinasi (Rsquare) antara ketiga variabel secara bersama-sama $\left(\mathrm{X}_{4}\right)$ dan kompetensi mahasiswa PPL (Y) sebesar 0,427; bahwa sumbangan efektif ketiga variabel bebas secara bersama-sama terhadap kompetensi mahasiswa PPL sebesar $42,7 \%$.

\section{SIMPULAN DAN SARAN}

\section{Simpulan}

Berdasarkan permasalahan, tujuan penelitian, hasil analisis dan pembahasan yang telah dipaparkan, maka dapat disimpulkan bahwa: (1) Prestasi mahasiswa pada mata kuliag Rancangan Pendidikan dan Pembelajaran berkontribusi terhadap kompetensi mahasiswa PPL jurusan pendidikan Teknik Sipil dan Perencanaan Universitas Negeri Makassar dengan sumbangan sebesar 9,950\%; (2) Prestasi mahasiswa pada mata kuliah Profesi Keguruan berkontribusi terhadap kompetensi mahasiswa PPL jurusan pendidikan Teknik Sipil dan Perencanaan Universitas Negeri Makassar dengan sumbangan sebesar 14,025\%; (3) Prestasi mahasiswa pada mata kuliah Interaksi Pembelajaran berkontribusi terhadap kompetensi mahasiswa PPLjurusan pendidikan Teknik Sipil dan Perencanaan Universitas Negeri Makassar dengan sumbangan sebesar 18,725\%; dan (4) Prestasi mahasiswa pada mata kuliah Rancangan Pendidikan dan Pembelajaran, Profesi Keguruan, dan Interaksi Pembelajaran secara bersama-sama berkontribusi terhadap kompetensi mahasiswa PPL jurusan pendidikan Teknik Sipil dan Perencanaan Universitas Negeri Makassar dengan sumbangan sebesar $42,7 \%$;

\section{Saran}

Setelah mendapatkan kesimpulan dari penelitian dimana secara umum semua varaibel mempunyai kontribusi yang sangat rendah terhadap kompetensi mahasiswa PPL, maka temuan penelitian ini akan menjadi bahan atau gambaran dan masukan bagi Pengelolah jurusan Pendidikan Teknik Sipil dan Perencanaan Universitas Negeri Makassar. Beberapa hal yang merupakan faktor penghambat kompetensi mahasiswa PPL tidak maksimal. (1). Kurangnya kompetensi pedagogik mahasiswa PPL saat melaksanakan Praktik Pengalaman Lapangan khususnya kepercayaan diri pada saat berada di depan kelas, pembuatan perangkat pembelajaran yang belum maksimal karena kurangnya praktik/latihan yang dilakukan oleh mahasiswa dikampus sebelum turun ke lapangan untuk 
melaksanakan PPL; (2). Kurang maksimalnya pembelajaran praktik/latihan khususnya dalam pembelajaran micro teaching karena kurangnya sarana dan prasarana pendukung terutama tidak adanya laboratorium micro teaching sebagai sarana praktik yang berakibat pada kurang maksimalnya persiapan mahasiswa sebelum melaksanakan PPL; (3). Mengadakan peninjauan ulang terhadap pengawasan (Pemantauwan, supervise, evaluasi) proses pembelajaran dan penggunaan dosen dari luar Fakultas Teknik sehingga pembelajaran mata kuliah kependidikan berjalan dengan maksimal.

\section{DAFTAR PUSTAKA}

Anonim .(2005). Kamus Besar Bahasa Indonesia Edisi IV. Jakarta:Balai Pustaka.

Depdiknas. (2003). Undang-Undang RI Nomor 20 Tahun 2003 tentang sistem pendidikan nasional. Jakarta:Depertemen Pendidikan nasional Republik Indonesia.

Depdiknas. (2005). Undang-Undang RI Nomor 14 Tahun 2005 tentang guru dan dosen. Jakarta:Depertemen Pendidikan nasional Republik Indonesia.

Depdiknas. (2010). Peraturan Pemerintah RI Nomor 17 Tahun 2010 tentang pengelolaan dan penyelenggaraan pendidikan. Jakarta:Depertemen Pendidikan nasional Republik Indonesia.

Depdiknas. (2005). Peraturan Pemerintah RI Nomor 19 Tahun 2005 tentang Standar Nasional Pendidikan. Jakarta: Depertemen Pendidikan nasional Republik Indonesia.

Depdiknas. (2007). Peraturan Menteri Diknas Nomor 41 Tahun 2007 tentang Standar Proses. Jakarta:Depertemen Pendidikan Nasional Republik Indonesia

Santoso, D. (2011). Kata Sambutan. Diakses pada tanggal 15 Oktober 2013 dari http://www.dikti.go.id/id/profil-dikti/ kata-sambutan-dirjen/?lang=id.
Isaac, S. \& Michael, W.B. (1983). Hand Book In Research and Evaluation. From The California.

Harahap. (2013). Anak Indonesia Bisa Hebat Jika Gurunya Hebat. Diakses Tanggal 21 Oktober 2013 dari http:// kampus.okezone.com/read/2013/06/12/ 560/820856/anak-indonesia-bisa-hebatjika-gurunya-hebat.

Rusmin. (2003). Kompetensi Guru Menyongsong Kurikulum Berbasis Kompetensi. Diakses pada tanggal 12 agustus 2013 dari http://Indonesia.com/ bpost/042003/22/opini/opini1.html.

Sugiono.(2012). MetodePenelitian Pendidikan. (Pendekatan Kuantitatif, Kualitatif, dan $R \& D)$. Bandung:Alfabeta.

Sukardi. (2003). Metodologi Penelitian Pendidikan (Kompetensi dan Praktiknya). Jakarta:PT.Bumi Aksara.

Supriano. (2013). Hardiknas, harkitnas, dan masa depan yang lebih baik. Jurnal Pewara DINAMIKA UNY, Volume 14.Nomor 64 Juni 2013.Hal 44-45

Universitas Negeri Yogyakarta. (2013). Panduan $K K N-P P L$.Yogyakarta:LPPMP UNY.

Universitas Negeri Yogyakarta. Panduan pengajaran mikro.Yogyakarta: LPPMP UNY.

Universitas Negeri Yogyakarta .(2013). Pedoman Penulisan Tesis dan Desertasi. Yogyakarta:PPs UNY.

Universitas Negeri Makassar. (2012). Panduan PPL.Makassar:Pusat PPL UNM.

Wasilatul, Fatriya \& Edy.(2013).Dinamika Kompetensi Profesional dan Budaya Belajar Melalui Penerapan Pembelajaran Metode Information Search pada Mata Kuliah Analisis Vektor. Jurnal Penelitian Pendidikan. Volume 5, No,2 Desember 2013. Hal 906-916.

Sanjaya, W. (2008). Perencanaan dan Desain Sistem Pembelajaran.Jakarta: Kencana Prenada Media Group. 